\title{
BODY PIGMENTATION AND MERISTIC CHARACTERISTICS OF BALKAN GOLDEN LOACH (Sabanejewia balcanica) FROM THE WATER CATCHMENT AREA OF THE RIVER SAVA
}

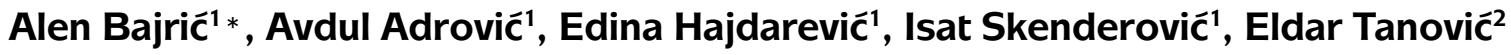 \\ 'University of Tuzla, Faculty of Natural Sciences and Mathematics. Univerzitetska 4, Tuzla, BiH \\ 2J. P. Elektroprivreda BiH (Public Enterprise Electric Utility of Bosnia and Herzegovina), Mije Keroševića Guje \\ br. 1, Tuzla, BiH
}

*Corresponding Author, Email: alen.bajric@untz.ba

\section{ARTICLE INFO}

Received: 27 October 2017

Received in revised form: 15 December 2017

Accepted: 10 January 2018

Available online: 21 February 2018

\begin{abstract}
The taxonomic research of eight populations of Sabanejewia balcanica from the water catchment area of the river Sava included the analysis of the meristic characteristics and pigmentation of their bodies. The analyzed sample contained 98 specimens collected in the areas of the rivers Turija, Gostelja, Brka, Suturlija, Suha, Tinja and Trebačka. The aim of this paper was to specify the meristic and pigment characteristics of this species at the location of the water catchment area of the river Sava, which are frequently used in describing new taxa. The meristic traits investigation included the analysis of the number of rays in dorsal, ventral, pectoral, anal and caudal fins. In the analysis of body pigmentation, the number and arrangement of suborbital spines, blotches or spots were determined. The results of this research indicated that there were no intrapopulation differences in Sabanejewia balcanica from the water catchment area of the river Sava in terms of meristic characteristic and body pigmentation.
\end{abstract}

Keywords:

Cobitidae

Rays

Fins

Intrapopulation differences
Bajrić, A., Adrović, A., Hajdarević, E., Skenderović, I., Tanović, E. (2018): Body pigmentation and meristic characteristics of Balkan golden loach (Sabanejewia balcanica) from the water catchment area of the river Sava. Croatian Journal of Fisheries, 76, 72-79. DOI: 10.2478/cjf-2018-0009.

\section{INTRODUCTION}

It is known that populations of Sabanejewia balcanica (Karaman, 1922) can differ in terms of body pigmentation, morphology and habitat. The differences in the stated characteristics between these populations were confirmed, and from very close localities some populations were even regarded as a separate subspecies, but such interpretations require many reviews (Kottelat and Freyhof, 2007).

The genus Sabanejewia (Vladykov, 1929) is diverse in Europe (Perdices et al., 2003), even though the taxonomic and phylogenetic position of many taxa is sometimes disputed and is still uncertain. There are eight species of this genus in European waters (Kottelat and Freyhof, 2007), with many populations being described as controversial species, subspecies or clinal variations (Ludwig et al., 2001). This species inhabits upper or middle parts of rivers and streams with sand and gravel bottom (Mrakovčić et al., 2006).

The data on morphometry, ecology and biology of $S$. balcanica in Bosnia and Herzegovina is very scarce and discontinuous. The greatest number of domestic publications 
very often keeps the old scientific name of this species, i.e. subspecies (Cobitis aurata balcanica) (Sofradžija, 2009). Karaman (1963) described the population of this species from the rivers Saturlija and Široka as a subspecies mainly based on the body pigmentation and meristic characteristics. Bajrić (2017) highlighted an extremely diverse morphological and genetic structure of the populations of $S$. balcanica in the water catchment area of the river Sava.

The analyzed individuals have an eel-shaped body, but not to the same extent as in other Cobitidae fish species. At the sides of the head, there are distinct suborbital spines which can sometimes be concealed but are in any event very distinct and perceptible to the touch. A ridge, on the dorsal side of the tail region, is very distinct, which is a significant characteristic for distinguishing them from other species of the family Cobitidae which inhabits our waters.

The aim of this research was to analyze the pigmentation and meristic characteristics of different populations of $S$. balcanica from the water catchment area of the river Sava, and determine their relation to other similar researches in the Balkan area.

\section{MATERIALS AND METHODS}

The analyzed specimens were collected at eight sites of the water catchment area of the river Sava during 2015. The analyzed populations of $S$. balcanica were gathered in the areas of the rivers Turija, Gostelja, Oskova, Brka, Suturlija, Suha, Tinja and Trebačka, which geographically belong to the northern part of Bosnia and Herzegovina (Table 1). Some of the mentioned sites were geographically closely connected, whereas others were distant areas (Fig. 1). The population of this species from the river Saturlija was also analyzed, which was formerly described as a separate subspecies. The individuals were collected by nets and electrofishing (IG 600 ), with power output of $1.3 \mathrm{~kW}$. The determination of

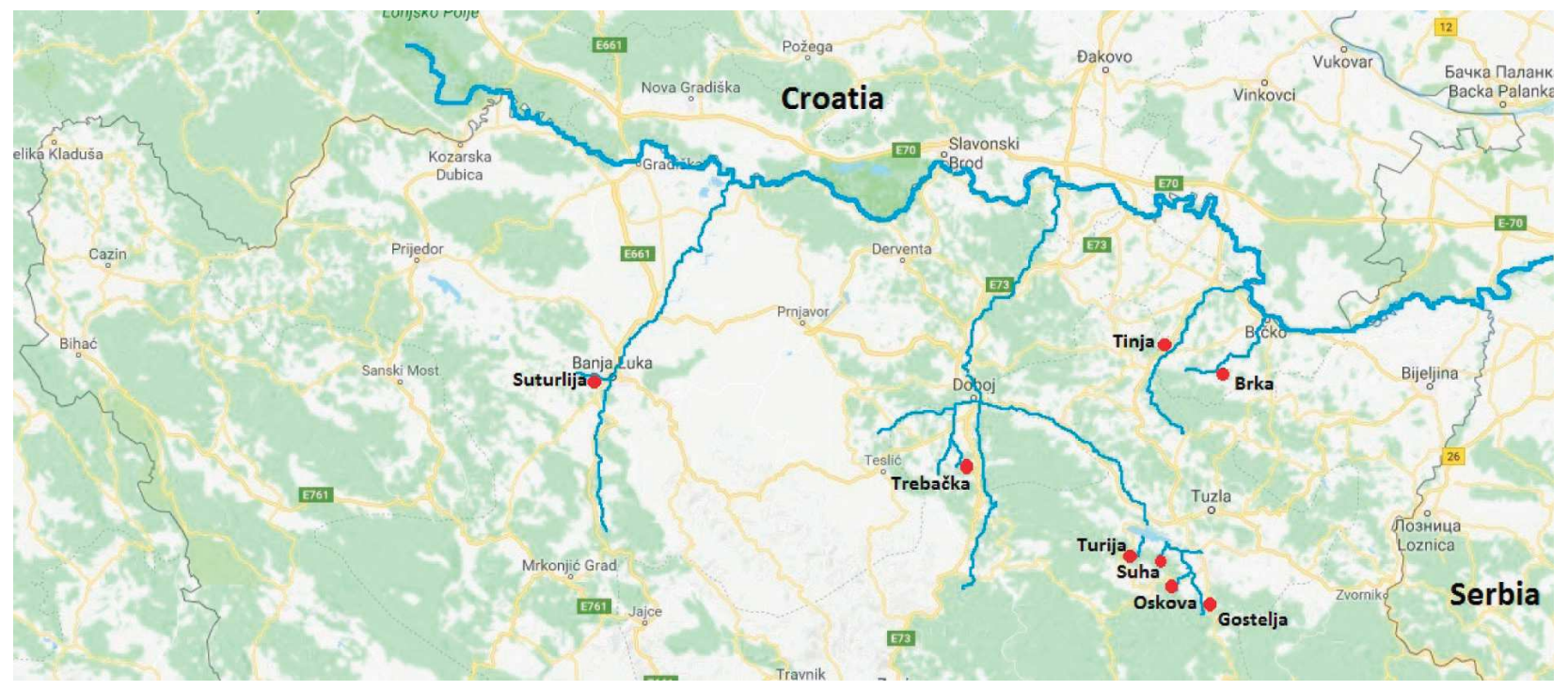

Fig 1. Research area (north-eastern Bosnia) (excerpt from Google maps)

Table 1. Characteristics of research locality and number of analyzed individuals of S. balcanica

\begin{tabular}{lccc}
\hline \hline Locality & \multicolumn{1}{c}{ Coordinates } & Catchment area & $\mathrm{N}$ \\
\hline Turija & $44^{\circ} 30^{\prime} 48.4^{\prime \prime} \mathrm{N} 18^{\circ} 25^{\prime} 53.4^{\prime \prime} \mathrm{E}$ & Spreča, Bosna, Sava & 11 \\
Gostelja & $44^{\circ} 22^{\prime} 49.4^{\prime \prime} \mathrm{N} 18^{\circ} 40^{\prime} 05.8 \mathrm{E}$ & Spreča, Bosna, Sava & 24 \\
Oskova & $44^{\circ} 26^{\prime} 30.0^{\prime \prime} \mathrm{N} 18^{\circ} 39^{\prime} 02.2^{\prime \prime} \mathrm{E}$ & Spreča, Bosna, Sava & 12 \\
Brka & $44^{\circ} 46^{\prime} 58.5^{\prime \prime} \mathrm{N} 18^{\circ} 42^{\prime} 19.8^{\prime \prime} \mathrm{E}$ & Sava & 17 \\
Suturlija & $44^{\circ} 45^{\prime} 07.3^{\prime \prime} \mathrm{N} 1709^{\prime} 43.2^{\prime \prime} \mathrm{E}$ & Vrbas, Sava & 11 \\
Suha & $44^{\circ} 27^{\prime} 51.7^{\prime \prime} \mathrm{N} 18^{\circ} 35^{\prime} 15.5^{\prime \prime} \mathrm{E}$ & Spreča, Bosna, Sava & 10 \\
Tinja & $44^{\circ} 42^{\prime} 22.9^{\prime \prime} \mathrm{N} 18^{\circ} 29^{\prime} 09.9^{\prime \prime} \mathrm{E}$ & Sava & 9 \\
Trebačka & $44^{\circ} 37^{\prime} 53.5^{\prime \prime} \mathrm{N} 18^{\circ} 01^{\prime} 04.7^{\prime \prime} \mathrm{E}$ & Usora, Bosna, Sava & 4 \\
& & & 98 \\
\hline \hline
\end{tabular}


the individuals was carried out according to Kottelat and Freyhof (2007). The body pigmentation was determined visually, within which the number and distribution of dark spots or dots were observed. The meristic characteristics analyzed were the number of rays in the dorsal, anal, pectoral, ventral and caudal fins. In cases of unpaired fins, it was determined that there are the last two soft rays which are not completely separated, and there are differences in interpretation in the literature on this issue. In the majority of research papers, these two rays are treated as separate and complete ones, but there are also research papers where they are regarded as $1^{1 / 2}$. A light microscope and magnifying glass were used for these purposes. The complete analysis was conducted in the laboratory for zoology at the Faculty of Natural Sciences and Mathematics in Tuzla. Data processing included descriptive statistics which was carried out using Microsoft Office Excel and Statistica 10.

\section{RESULTS}

\section{Body pigmentation}

The analysis determined that there are certain differences between the analyzed individuals in terms of their body pigmentation. However, those pigmentations are not so distinct that one population could be singled out. Different types of pigmentation were present within the individuals of all the analyzed populations. Their body is mostly marble-colored, and there are 8-12 dark blotches along the sideline which are not necessarily complete, and this particularly refers to the tail region. The back of the analyzed individuals is also mottled, with clear dark blotches whose number varies from 8 to 11 . The dorsal fin, caudal fin and anal fin can have series of dark spots. At the base of caudal fin, there are two dark spots which are extended toward its central part, and they have the tendency to merge, which was confirmed in some individuals. Different types of body pigmentation are shown in figures 2, 3, 4 and 5.

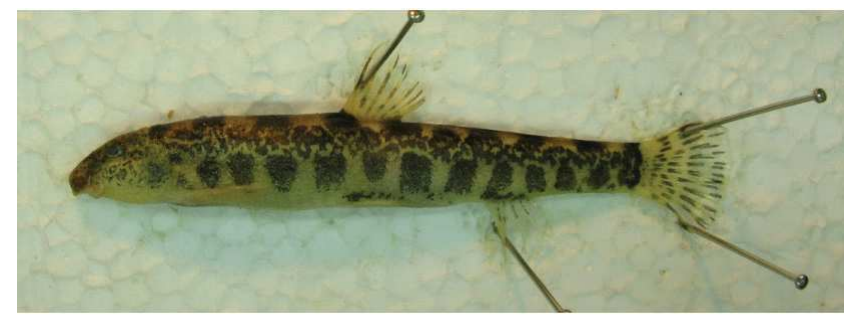

Fig 2. Body pigmentation-type I (river Gostelja) (photo by Alen Bajrić)

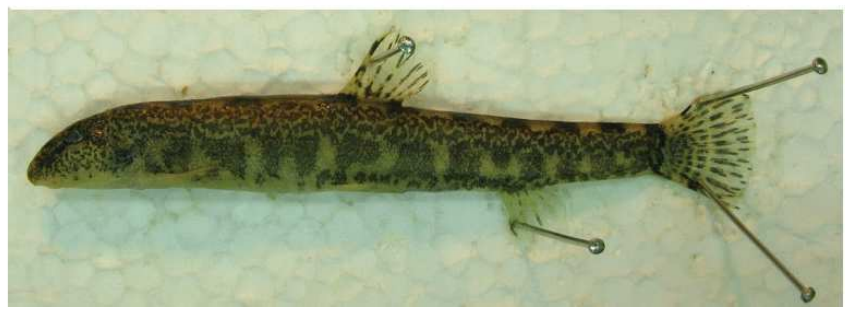

Fig 3. Body pigmentation - type II (river Gostelja) (photo by Alen Bajrić)

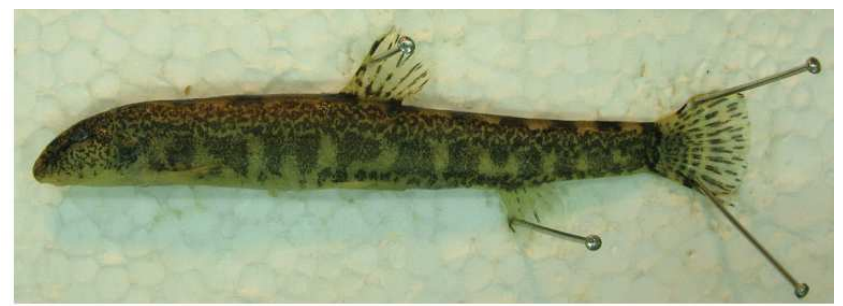

Fig 4. Body pigmentation - type III (river Oskova) (photo by Alen Bajrić)

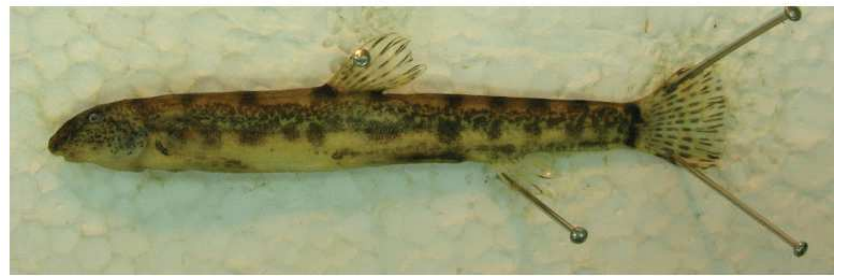

Fig 5. Body pigmentation - type IV (river Trebačka) (photo by Alen Bajrić)

Table 2. Fin formulas of investigated populations of S. balcanica

\begin{tabular}{|c|c|c|c|c|c|}
\hline Locality/fin & Dorsalia & Analia & Pectoralia & Ventralia & Caudalia \\
\hline Turija & II $6-8\left(6-7^{1 / 2}\right)$ & II 5-6 $\left(5-5^{1 / 2}\right)$ & I-II 6-8 & $15-6$ & $13-15$ \\
\hline Gostelja & II $7-8\left(7-7^{1 / 2}\right)$ & II 5-6 $\left(5-5^{1 / 2}\right)$ & $17-8$ & 16 & $13-14$ \\
\hline Oskova & II 7 & II $5\left(5-5^{1 / 2}\right)$ & $17-8$ & 16 & $13-15$ \\
\hline Brka & II $7-8\left(7-7^{1 / 2}\right)$ & II 5-6 $\left(5-5^{1 / 2}\right)$ & $17-8$ & $15-6$ & $13-14$ \\
\hline Suturlija & II $8\left(7^{1 / 2}\right)$ & II $6\left(5^{1 / 2}\right)$ & $17-8$ & 16 & $13-15$ \\
\hline Suha & II $7-8\left(7-7^{1 / 2}\right)$ & II 5-6 $\left(5-5^{1 / 2}\right)$ & $18-9$ & 16 & 13 \\
\hline Tinja & II $7-8\left(7-7^{1 / 2}\right)$ & II 5-6 $\left(5-5^{1 / 2}\right)$ & 18 & 16 & 14 \\
\hline Trebačka & II $7-8\left(7-7^{1 / 2}\right)$ & II $6\left(5-5^{1 / 2}\right)$ & 18 & 16 & 13 \\
\hline
\end{tabular}


Table 3. Frequency of hard and soft fin rays of research populations S. balcanica

\begin{tabular}{|c|c|c|c|c|c|c|c|c|}
\hline \multirow{2}{*}{ Locality } & \multicolumn{2}{|c|}{ Dorsalia } & \multicolumn{2}{|c|}{ Analia } & \multicolumn{2}{|c|}{ Pectoralia } & \multicolumn{2}{|c|}{ Ventralia } \\
\hline & Hard & Soft & Hard & Soft & Hard & Soft & Hard & Soft \\
\hline Turija & II & $6-8$ & II & $5-6$ & $|-I|$ & $6-8$ & I & $5-6$ \\
\hline $\bar{x} \mathrm{SD}$ & $2 \pm 0.0$ & $7 \pm 0.44$ & $2 \pm 0.0$ & $5.09 \pm 0,3$ & $1.36 \pm 0,5$ & $7.09 \pm 0.83$ & $1 \pm 0,0$ & $5.7 \pm 0.46$ \\
\hline \multirow[t]{3}{*}{ (\%) } & II (100) & $6(9.09)$ & II (100) & 5 (90.9) & I (63.6) & $6(27.2)$ & $\mathrm{I}(100)$ & $5(27.2)$ \\
\hline & & 7 (81.8) & & 6 (9.09) & II (36.3) & $7(36.3)$ & & $6(72.7)$ \\
\hline & & 8 (9.09) & & & & $8(36.3)$ & & \\
\hline Gostelja & II & $7-8$ & II & $5-6$ & 1 & $7-8$ & 1 & 5 \\
\hline $\bar{x} \mathrm{SD}$ & $2 \pm 0.0$ & $7.37 \pm 0.49$ & $2 \pm 0.0$ & $5.2 \pm 0.41$ & $1 \pm 0.0$ & $7.41 \pm 0.5$ & $1 \pm 0.0$ & $5 \pm 0.0$ \\
\hline \multirow[t]{2}{*}{ (\%) } & II (100) & 7 (62.5) & II (100) & 5 (79.1) & $\mathrm{I}(100)$ & 7 (58.3) & $\mathrm{I}(100)$ & $5(100)$ \\
\hline & & $8(37.5)$ & & $6(20.8)$ & & 8 (41.6) & & \\
\hline Oskova & II & 7 & II & 5 & I & $7-8$ & 1 & 5 \\
\hline $\bar{x} \mathrm{SD}$ & $2 \pm 0.0$ & $7 \pm 0.0$ & $2 \pm 0.0$ & $5 \pm 0.0$ & $1 \pm 0.0$ & $7.66 \pm 0.49$ & $1 \pm 0.0$ & $5 \pm 0.0$ \\
\hline \multirow[t]{2}{*}{ (\%) } & II (100) & 7 (100) & II (100) & $5(100)$ & $\mathrm{I}(100)$ & $7(33.3)$ & $\mathrm{I}(100)$ & $5(100)$ \\
\hline & & & & & & $8(66.6)$ & & \\
\hline Brka & II & $7-8$ & II & $5-6$ & 1 & $7-8$ & 1 & $5-6$ \\
\hline $\bar{x} \mathrm{SD}$ & $2 \pm 0.0$ & 7.520 .51 & $2 \pm 0.0$ & $5.82 \pm 0.39$ & $1 \pm 0.0$ & $7.94 \pm 0.24$ & $1 \pm 0.0$ & $5.88 \pm 0.33$ \\
\hline \multirow[t]{2}{*}{ (\%) } & II (100) & 7 (47.05) & II (100) & $5(17.6)$ & $\mathrm{I}(100)$ & $7(5.88)$ & $\mathrm{I}(100)$ & 5 (11.7) \\
\hline & & 8 (52.9) & & $6(82.3)$ & & 8 (94.1) & & $6(88.2)$ \\
\hline Suturlija & II & 8 & II & 6 & I & $7-8$ & 1 & 6 \\
\hline $\bar{x} \mathrm{SD}$ & $2 \pm 0.0$ & $8 \pm 0.0$ & $2 \pm 0.0$ & $6 \pm 0.0$ & $1 \pm 0.0$ & $7.9 \pm 0.3$ & $1 \pm 0.0$ & $6 \pm 0.0$ \\
\hline \multirow[t]{2}{*}{ (\%) } & II (100) & 8 (100) & II (100) & $6(100)$ & $\mathrm{I}(100)$ & 7 (9.09) & $\mathrm{I}(100)$ & 6 (100) \\
\hline & & & & & & $8(90.9)$ & & \\
\hline Suha & II & $7-8$ & II & $5-6$ & 1 & $8-9$ & 1 & 6 \\
\hline $\bar{x} \mathrm{SD}$ & $2 \pm 0.0$ & $7 . .3 \pm 0.48$ & $2 \pm 0.0$ & $5.3 \pm 0.48$ & $1 \pm 0.0$ & $8.1 \pm 0.31$ & $1 \pm 0.0$ & $6 \pm 0.0$ \\
\hline \multirow[t]{2}{*}{ (\%) } & II (100) & $7(30)$ & II (100) & $5(70)$ & $\mathrm{I}(100)$ & $8(90)$ & $\mathrm{I}(100)$ & $6(100)$ \\
\hline & & $8(70)$ & & $6(30)$ & & $9(10)$ & & \\
\hline Tinja & II & $7-8$ & II & $5-6$ & I & 8 & 1 & 6 \\
\hline $\bar{x} \mathrm{SD}$ & $2 \pm 0.0$ & $7.66 \pm 0.5$ & $2 \pm 0.0$ & $5.66 \pm 0.5$ & $1 \pm 0.0$ & $8 \pm 0.0$ & $1 \pm 0.0$ & $6 \pm 0.0$ \\
\hline \multirow[t]{2}{*}{ (\%) } & II (100) & 7 (33.3) & II (100) & $5(33,3)$ & $\mathrm{I}(100)$ & 8 (100) & $\mathrm{I}(100)$ & $6(100)$ \\
\hline & & $8(66.6)$ & & $6(66,6)$ & & & & \\
\hline Trebačka & II & $7-8$ & II & 6 & 1 & 8 & 1 & 6 \\
\hline $\bar{x} \mathrm{SD}$ & $2 \pm 0.0$ & $7.75-0.5$ & $2 \pm 0.0$ & $6 \pm 0.0$ & $1 \pm 0.0$ & $8 \pm 0.0$ & $1 \pm 0.0$ & $6 \pm 0.0$ \\
\hline \multirow[t]{2}{*}{ (\%) } & II (100) & $7(25)$ & II (100) & $6(100)$ & $\mathrm{I}(100)$ & 8 (100) & $\mathrm{I}(100)$ & 6 (100) \\
\hline & & $8(75)$ & & & & & & \\
\hline
\end{tabular}




\section{Meristic characteristics}

The results of the meristic research at the localities are presented in Table 2 . In the majority of individuals from the Turija, the dorsal fin had seven branched rays $(81.81 \%)$, while in all the individuals from this area, there was one unbranched ray.

At this locality, there was a constant number of unbranched rays in the anal fin and there were five branched rays $(90.90 \%)$ in the majority of individuals. In the pectoral fin of the individuals one or two unbranched rays were determined, whereas in 63.63 percent of individuals there was one unbranched ray. The number of branched rays ranged from six to eight, whereas there were seven and eight branched rays in 36.36 percent of individuals. In the ventral fin, there was one unbranched ray in all individuals, while there were six branched rays in 81.81 percent (Table 3).

In individuals from the Gostelja, there were two unbranched rays in the dorsal fin. There were seven branched rays in 62.50 percent of individuals from this sample. In the anal fin, there were two unbranched rays and there were five branched rays in the majority of them $(79.16 \%)$. In the pectoral and ventral fins, there was one unbranched ray in each fin. In all individuals from this locality, there were six branched rays in the ventral fin, while there were seven branched rays in the pectoral fin in 58.33 percent of individuals (Table 3 ).

A constant number of branched and unbranched rays was determined in the dorsal, anal and ventral fins in the individuals from the Oskova (Table 3). The pectoral fin had a constant number of unbranched rays, and eight branched rays were determined in 66.66 percent of individuals.

With regard to the individuals from the Brka, a constant number of unbranched rays in all fins was determined (Table 3). There were eight branched rays in the dorsal fin in 52.94 percent of individuals, while in 82.35 percent of individuals there were six branched rays in the anal fin. In the majority of individuals, there were eight branched rays in the pectoral fin $(94.11 \%)$ and six branched rays in the ventral fin (88.00\%).

A constant number of branched and unbranched rays was determined in the dorsal, anal and ventral fins in the investigated individuals of $S$. balcanica from the river Suturlija (Table 3). In all the analyzed individuals from this locality, there was one unbranched ray in the pectoral fin, and there were eight branched rays in this fin in the majority of them (90.90\%).

In the individuals from the river Suha, there were mostly two unbranched and seven branched rays in the dorsal fin, and two unbranched and five branched rays in the anal fin $(70.00 \%)$. In all individuals from this area, the anal fin had one unbranched ray and six branched rays, while in 90.00 percent of individuals, the pectoral fin had one unbranched and eight branched rays (Table 3 ). In the individuals from the river Tinja, a constant number of rays in the pectoral and ventral fins were determined in all the sampled individuals. In this area, in 66.66 percent of individuals, there were two branched and eight unbranched rays, while there were two unbranched and six branched rays in the anal fin (Table 3).

In the analyzed individuals from the river Trebačka, a constant number of rays was determined in the anal, pectoral and ventral fins, while in 75.00 percent of individuals, there were two unbranched and eight branched rays in the dorsal fin (Table 3).

The number of rays in the caudal fins of all analyzed populations was between 13 and 15 (Table 2).

\section{DISCUSSION}

\section{Body pigmentation}

The populations of Balkan golden loach show certain differences in the body pigmentation, which caused different interpretations and classification of some populations as separate species. Kottelat and Freyhof (2007) treat all Danube and Balkan populations as one species, but it is necessary to research it again.

Mrakovčić et al. (2006) state that this species has 12-16 dark brown spots at the sides, and on the back of this species there can be 10-16 of these spots. According to Kottelat and Freyhof (2007), at the sides and on the back of this species, 10-17 of these spots can be noticed, or rarely 8-9. Simonovic (2006) reports that this species has 10-15 darker spots at the sides. Vukovic and Ivanović (1971) indicate that, at the sides of this species, there are 12-16 dark spots, and on the back, there are 10-12 reddish spots, although the mentioned authors observed this species as differentiated into many subspecies, which can cause confusion. Economidis and Nalbant (1996) suggest that the ground color of Sabanejevia aurata balcanica (Karaman, 1922) is orange-brown, with 3-6 dark spots on the back before the dorsal fin. Dorso-lateral pigmentation is based on the presence of $7-14$, most frequently $10-11$, grey to dark generally square-like spots. Head and its sides are covered with small dark brown spots, where there can be a blackish stripe from the anterior rim of the orbit to the tip of the snout. From the research conducted by Iftime (2002), it can be noticed that all Romanian populations and described subspecies of the genus Sabanejewia show a great variability, and there is not a unique characteristic for only one population. Even if 
Table 4. The number of hard and soft fin rays from the European populations

\begin{tabular}{|c|c|c|c|c|}
\hline Locality/fin & Dorsalia & Analia & Pectoralia & Ventralia \\
\hline Turija (BiH) & II 6-8 & II 5-6 & I-II 6-8 & $15-6$ \\
\hline Gostelja (BiH) & 11 7-8 & |I 5-6 & $17-8$ & 16 \\
\hline Oskova (BiH) & 117 & 115 & $17-8$ & 16 \\
\hline Brka (BiH) & $117-8$ & II 5-6 & $17-8$ & $15-6$ \\
\hline Suturlija (BiH) & II 8 & II 6 & $17-8$ & 16 \\
\hline Suha $(\mathrm{BiH})$ & 11 7-8 & II 5-6 & $18-9$ & 16 \\
\hline Tinja (BiH) & II 7-8 & II 5-6 & 18 & 16 \\
\hline Trebačka (BiH) & II 7-8 & 116 & 18 & 16 \\
\hline Bijela (Delić et al., 2003-Cro) & $|-||| 6-8$ & $|-| \mid 5-7$ & I-III 5,7-9 & I-II 5-6 \\
\hline Petrinjčica (Delić et al., 2003-Cro) & $1-1 \mid 7-8$ & $|-|||$ 5-6 & $|-| \mid 5-8$ & $|-| I \mid$ 4-6 \\
\hline Kupa (Šumer and Povž, 2000-Slo) & $|-| \mid 6-7$ & $|-| \mid 4-6$ & $17-8$ & II 6-7 \\
\hline Lim (Marić and Milošević, 2010-Mno) & I-II 6-7 & $|-| \mid 6$ & $17-8$ & 116 \\
\hline Vardar (Grupče and Dimovski, 1976-Mcd) & III (6) 7-8 & III $5(6)$ & I (7) 8-9 & II (5) 6 (7) \\
\hline Loborec (Vasil'eva and Ráb, 1992-Svk) & III 6-7 & III 5-6 & $17-8$ & II 5 \\
\hline Doiransko I. (Economidis and Nalbant, 1996-Gr) & III $7(6)$ & $\| 5$ & 18 & 17 \\
\hline Evros (Economidis and Nalbant, 1996-Gr) & III 7 & II 5 & 18 & 17 \\
\hline
\end{tabular}

there is a difference, it is present only in one individual and not in the whole population. Most morphometric and pigmentation characteristics have a variable frequency in all populations. A wide range of color variants or morphological characteristics can be regarded as a "local race" which is most frequently influenced by ecological factors. Thus, Bānārescu et al. (1972) determined that a different level of pigmentation in S. balcanica and in other related species or subspecies depends on the depth of water and longitudinal section of a watercatchment area. Different phenotypic characteristics of the populations of Balkan golden loach in Croatia were noted by Buj et al. (2008), and they are related to the fact that individuals from the rivers Drava and Voćinska have two dark separated spots at the base of the caudal fin, which merge into a dark line in individuals from Petrinjčica and Rijeka.

\section{Meristic characteristics}

The obtained results for the meristic characteristics of S. balcanica are compared with the available literature data. According to the latest literature data, the last two soft rays of unpaired fins are marked as $1^{1 / 2}$ due to the fact that they are not completely separated and they share the same pterygiophore (Kottelat and Freyhof, 2007).
This method of interpreting the meristic characteristics of fins is also noted in the work of Buj et al. (2014). For the purpose of arranging and easier comparison of these characteristics with the available literature data, these cases were represented as separate and complete rays (Table 4). Buj et al. (2008) determined a variable number of fin rays of some Croatian populations, which ranged from I to III hard rays and 6-9 soft rays in the dorsal fin, from I to II hard rays and 5-7 soft rays in the anal fin, from I to II hard rays and 6-8 soft rays in the pectoral fin, from I to II hard rays and 5 to 7 soft rays in the ventral fin, and 13-15 in the caudal fin.

Karaman (1963) described the population of this species from the river Saturlija as a separate subspecies based on the body pigmentation and meristic characteristics. The analysis of these characteristics in our research did not indicate the previously mentioned differences.

There are certain differences in the body pigmentation among the analyzed populations, but based on it, it is impossible to isolate any population because different body pigmentations occur within all the analyzed populations.

Meristic characteristics of $S$. balcanica also show certain variations but it is impossible to isolate any population which provides the basis for determining the intrapopulation variation of these characters. 


\section{SAŽETAK}

\section{PIGMENTACIJA TIJELA I MERISTIČKA OBILJEŽJA BALKANSKOG ZLATNOG VIJUNA (Sabanejewia balcanica) IZ SAVSKOG SLIVA}

Taksonomska istraživanja osam populacija Sabanejewia balcanica iz sliva rijeke Save obuhvatila su analizu merističkih karakteristika i pigmentaciju njihovog tijela. Analizirani uzorak je brojao 98 jedinki koje su prikupljene na lokalitetima rijeke Turije, Gostelje, Oskove, Brke, Suturlije, Suhe, Tinje i Trebačke. Cilj ovog rada bio je ukazati na merističke i pigmentacijske karakteristike ove vrste na području sliva rijeke Save, koje su često korištene u opisivanju podvrsta ili novih vrsta. Meristička istraživanja obuhvatila su analizu broja žbica u perajama, do kojih smo došli upotrebom lupe i svjetlosnog mikroskopa. U okviru analize pigmentacije tijela utvrđen je broj i raspored suborbitalnih bodljica, mrlja ili pjega. Rezultati ovog istraživanja su pokazali da ne postoje međupopulacijske razlike Sabanejewia balcanica iz slivnog područja rijeke Save u pogledu merističkih karakteristika i pigmentacije tijela.

Ključne riječi: Cobitidae, zrake, peraje, razlike $u$ međupopulaciji

\section{REFERENCES}

Bajrić, A. (2017): Ekološko-morfološke i fiziološke odlike balkanskog zlatnog vijuna Sabanejewia balcanica (Karaman, 1922) iz sliva rijeke Save. Doktorska disertacija. Univerzitet „Džemal Bijedic““ u Mostaru.

Bānārescu, P., Nalbant, T., Chelmu, S., (1972): Revision and geographical variation of Sabanejewia aurata in Romania and the origin of S. bulgarica and S. rornanica (Pisces, Cobitidae). Annotationes Zoologicae et Botanicae, Bratislava, 75, 1-49.

Buj, I., Podnar, M., Mrakovčić, M., Ćaleta, M., Mustafić, P., Zanella D., Marčić Z. (2008): Morphological and genetic diversity of Sabanejewia balcanica in Croatia. Folia Zool. 57, 100-110.

Buj, I., Šanda, R., Marčić, Z., Ćaleta, M., Mrakovčić, M. (2014): Combining morphology and genetics in resolving taxonomy - A systematic revision of Spined Loaches (Genus Cobitis; Cypriniformes, Actinopterygii) in the Adriatic watershed. PLoS ONE 9(6): e99833. doi:10.1371/journal.pone.0099833.

Delić, A., Kučinić, M., Bučar, M., Lazar, B., Mrakovčić, M. (2003): Morphometric and Meristic Characteristics of the Goldside Loach Sabanejewia balcanica (Cobitidae) in Central Croatia. Folia biologica (Krakow), vol 51 (2003). Supplement, 33-38.
Economidis, P. S., Nalbant, T. T. (1996): A study of the loaches of the genera Cobitis and Sabanejewia (Pisces, Cobitidae) of Greece with description of six new taxa. Trav. Mus. Natl. Hist. nat „Grigore Antipa“ 36, 295-347. Grupče, R., Dimovski, A. (1976): Morfološka karakteristika na predstavnicite od rodot Cobitis (Pisces, Cobitidae) vo Makedonija. Acta Musei Macedonici Scientarum Natur. 15, 2, 29-48.

Iftime, A. (2002): Considerations over the taxonomical status of the Balkan golden loach (Sabanejewia balcanica) (Pisces: Ostaryophysi: Cobitidae) in Romania and Republic of Moldova. Trav. Mus. Hist. Nat. „Grigore Antipa“ 44, 335-355.

Karaman, S. (1922): Uber eine neue Cobitis-Art aus Jugoslavien, Cobitis balcanica n. sp. Glasnik Kroatisches. Naturwissenschaftliches Gesellschaft, Zagreb, 34, 1-4

Karaman, M. (1963): Eine neue Unterart des Steinpeitzigers, Cobitis aurata bosniaca n. ssp. (Cobitidae, Pisces) aus Jugoslawien. Internationale Revue der Gesamten Hydrobiologie 48, 4, 629.

Kottelat, M. (1997): European freshwater fishes. Biologia Bratislava 52, 5, 1-271.

Kottelat, M., Freyhof, J. (2007): Handbook of European Freshwater Fishes. Kottelat. Cornol, Switzerland. Freyhof. Berlin, Germany.

Ludwig, A., Bohlen, J., Wolter, C., Pitra C. (2001): Phylogenetic relationships and historical biogeography of spined loaches (Cobitidae, Cobitis and Sabanejewia) as indicated by variability of mitochondrial DNA. Zoological Journal of the Linnean Society.131, 3, 381-392.

Marić, D., Milošević, D. (2010): First record and morphological characteristics of the Balkan golden loach Sabanejewia balcanica (Cobitidae) in Montenegro. Periodicum Biologorum, 112, 2, 149-152.

Mrakovčić, M., Brigić, A., Buj, I., Ćaleta, M., Mustafić, P., Zanella D. (2006): Crvena knjiga slatkovodnih riba Hrvatske. Ministarstvo kulture, Državni zavod za zaštitu prirode. Republika Hrvatska.

Perdices, A., Doadrio, I., Economidis, P. S., Bohlen, J., Banarescu, P. (2003): Pleistocene effect on the European freshwater fish fauna: double origin of the cobitid genus Sabanejewia in the Danube basin (Osteichthyes: Cobitidae). Mol. Phylogenet. Evol. 26, 289-299.

Simonović, P. (2006): Ribe Srbije. NNK Internacional. Biološki fakultet Beograd, Beograd.

Sofradžija, A. (2009): Slatkovodne ribe Bosne i Hercegovine. Vijeće kongresa bošnjačkih intelektualaca. Sarajevo 2009.

Šumer, S., Povž, M. (2000): Morphometric and meristic characters of the genera Cobitis and Sabanejewia (Cobitidae) in Slovenia. 49, 235-240.

Vasil'eva, E., Ráb, P. (1992): The spined loach, Sabanejew- 
ia aurata (Cobitidae) from the River Laborets. Voprosy Ikhtiologii, 32, 176- 181.

Vladykov, V. (1929): Sur un nouveau genre de Cobitides, Sabanejewia. Bulletin du Museum National d'Histoire Naturelle $1,2,85-90$.
Vuković, T., Ivanović, B. (1971): Slatkovodne ribe Jugoslavije. Zemaljski muzej BiH, Sarajevo, Posebno izdanje. 